\title{
Effect of biochar and Trichoderma application on fungal diversity and growth of Zea mays in a sandy loam soil
}

\author{
Olga Muter ${ }^{1 *}$, Lelde Grantina-levina ${ }^{1,2}$, Galina Makarenkova ${ }^{1,2}$, Dagnija Vecstaudza ${ }^{1}$, \\ Silvija Strikauska ${ }^{1,3}$, Turs Selga ${ }^{2}$, Raimonds Kasparinskis ${ }^{4}$, Solvita Stelmahere ${ }^{1}$, \\ Christoph Steiner ${ }^{5}$
}

\author{
${ }^{1}$ Institute of Microbiology and Biotechnology, University of Latvia, Jelgavas 1, Riga LV-1004, Latvia \\ ${ }^{2}$ Faculty of Biology, University of Latvia, Jelgavas 1, Riga LV-1004, Latvia \\ ${ }^{3}$ Latvia University of Agriculture, Liela 2, Jelgava LV-3001, Latvia \\ ${ }^{4}$ Faculty of Geography and Earth Sciences, University of Latvia, Jelgavas 1, Riga LV-1004, Latvia \\ ${ }^{5}$ University of Kassel, Faculty of Organic Agricultural Sciences, Steinstrasse 19, D-37213 Witzenhausen, Germany \\ ${ }^{\star}$ Corresponding author, E-mail: olga.mutere@lu.lv
}

\begin{abstract}
Abstract. Application of biochar (BC) to agricultural soils has raised global interest. BC could serve as a carrier for immobilization of beneficial microorganisms. Effect of straw-derived BC $\left(50 \mathrm{t} \mathrm{ha}^{-1}\right)$ with and without immobilized Trichoderma viride on the growth of maize in a sandy loam soil in Zemgale region (Latvia) was studied in a 128-day mini-field trial. Four treatment types were compared, i.e., without amendments [C], biochar [BC], biochar with T. viride [BCT], and T. viride [T]. The highest amount of Trichoderma spp. DNA was detected by qPCR in [BCT]. The obtained results demonstrated high heterogenity of soil samples. Addition of straw-derived BC with immobilized T. viride to sandy loam soil promoted survival of Trichoderma spp. and significantly $(p<0.05)$ increased maize growth. The highest germination index, i.e., $87.5 \%$, after 14 days was observed in the [BCT] treatment. These results provide new methods for the optimization of cultivation conditions for maize in Northern latitudes.
\end{abstract}

Key words: fungal abundance, maize, nutrient profile of biomass, qPCR, straw-derived biochar, Trichoderma viride. Abbreviations: $\mathrm{BC}$, biochar; $\mathrm{CFU}$, colony forming units; qPCR, quantitative polymerase chain reaction.

\section{Introduction}

Improvements in plant breeding and in agronomic practices have made maize (Zea mays L.) an economically important culture in the Northern latitudes. Latvia can be considered as a marginal area for maize growing, as maize response to adverse meteorological and crop management conditions is more expressed than that in the case of other crops, e.g., small grain cereals (Gaile 2012; Gaile, Arhipova 2015; Bartusevics, Gaile 2009).

Optimization of growth conditions for maize embraces a broad spectrum of agrotechnological approaches. In particular, recent studies have shown a positive effect of biochar (BC) on yield of maize (Rehman et al. 2016; Arif et al. 2017; Faloye et al. 2017; Gonzaga et al. 2017; Kerré et al. 2017; Naeem et al. 2017; Sarfraz et al. 2017). Addition of BC to soil affects its compaction, porosity, water content, permeability, as well as biochemical processes, which promote element cycles and energy flow (Chan 2007; Tan et al. 2017).

In field experiments on nutrient poor alkaline calcareous soil under a maize-wheat cropping system it has been shown that BC positively influences plant nutrition, crop productivity and soil quality (Arif et al. 2017). Sarfraz et al. (2017) tested the effect of BC ( 1 to $2 \%$ ) and nitrogen on the growth of maize in an alkaline calcareous soil, and found an increase of the water-holding capacity, total organic carbon, maize yield, stomatal conductance and nitrogen uptake in plants.

Germination rate, plant growth, $\mathrm{N}$ and $\mathrm{P}$ concentrations in maize biomass depended on the type of $\mathrm{BC}$ and its application rate (Gonzaga et al. 2017). In greenhouse experiments with maize, combination of $\mathrm{BC}$ with $\mathrm{Fe}$ fertilizer and elemental sulfur significantly increased root and shoot dry weight, grain weight, photosynthetic and transpiration rates, and stomatal conductance (Ramzani et al. 2016). The effect of $\mathrm{BC}$ composed of maize-cob residue and inorganic fertilizer on the yield of maize under a drip irrigation system was found to be synergistic (Faloye et al. 2017). Experiments with maize performed in arable soils under historical charcoal kilns (black spots, > 150 years enrichment, 2.2\%) in southern Belgium showed a higher maize yield by $23 \%$, compared with adjacent soils without chracoal; these results were attributed to soil physical effects, rather than to nutritional effects (Kerré et al. 2017).

$\mathrm{BC}$ in soil leads to changes in microbial community 
composition, accompanied by increased microbial biomass and enhanced enzyme activity (Lehmann et al. 2011). This indicates that $\mathrm{BC}$ can serve as a carrier for immobilization of beneficial microorganisms in biofertilizers (Głodowska et al. 2016).

Fungi influence soil fertility, decomposition, cycling of minerals and organic matter, plant health and nutrition. The ability of Trichoderma sp. to colonize plant roots suggests a potential for protection of plant health (Romão-Dumaresq et al. 2016). Biocontrol properties of Trichoderma (teleomorph Hypocrea, Ascomycota) have been intensively studied in different aspects with the aim to find means to avoid extensive use of agrochemicals. Immobilized and coimmobilized formulations with Trichoderma could be applied as biofertilizers and biopesticides (El-Katatny, Idres 2014; Rangel et al. 2015). Many Trichoderma bioinoculants are now commercially available (Stewart, Hill 2014).

Trichoderma is a well-known mycoparasite, which secretes cell-wall degrading enzymes and other bioactive compounds with antibiosis effect towards the target pathogen. Trichoderma atroviride SG3403 has shown high biocontrol activity against southern maize leaf blight pathogen Cochliobolus heterostrophus, by inducing maize defence gene expression against pathogen infection (Wang et al. 2015). Interation of Trichoderma virens with maize roots was observed to induce a systemic resistance, which reduced disease in above-ground parts of plants (Lamdan et al. 2015). A positive effect of Trichoderma harzianum on maize growth and root development, as well as increased protein levels and activities of $\beta-1,3$ glucanase, exochitinase, and endochitinase in both roots and shoots, were reported by Harman et al. (2004). was detected (Harman et al. 2004). Treatment of maize seeds with Trichoderma asperellum increased plasma membrane $\mathrm{H}^{+}$-ATPase activity in roots and shoots (Ĺopez-Coria et al. 2016).

It was hypothesized that application of $\mathrm{BC}$ enriched by Trichoderma in soils for maize cultivation can be a potential agrotechnological approach. The aim of this study was to test effect of straw-derived BC $\left(50 \mathrm{t} \mathrm{ha}^{-1}\right)$ with and without immobilized Trichoderma viride on growth of maize in a sandy loam soil in a 128-day mini-field trial. Changes in the fungal community and in abundance of Trichoderma spp. DNA were evaluated using culture-dependent methods and molecular tools.

\section{Materials and methods}

\section{Materials}

The straw BC was produced at BlackCarbon A/S (Denmark, http://blackcarbon.dk/unit/) from pelletized wheat straw at maximum pyrolysis temperature of $725^{\circ} \mathrm{C}$ with a residence time of $1 \mathrm{~h}$, at continuous flow with constant heating. The generated producer-gas had temperature $460{ }^{\circ} \mathrm{C}$. The bulk density of $\mathrm{BC}$ was $0.39 \mathrm{~g} \mathrm{~cm}^{-3}$. $\mathrm{BC}$ was divided into two fractions by sieving with a mesh size of $2 \mathrm{~mm}$ diameter. The physicochemical characteristics of the $\mathrm{BC}$ were as follows: $\mathrm{C}_{\text {tot }} 84.47 \% ; \mathrm{N}_{\text {tot }} 0.5 \%$; ash 9.5\%; $\mathrm{S}_{\text {tot }} 279.4 \mathrm{mg} \mathrm{kg}^{-1} ; \mathrm{BET}$ (Brunauer-Emmett-Teller) surface $2.90 \mathrm{~m}^{2} \mathrm{~g}^{-1} ; \mathrm{pH}_{\mathrm{KCl}} 8.96$ (Muter et al. 2014).

\section{Mini-field trial}

Soil was amended by BC and T. viride alone or in a mixture, according to the experimental setup. The following treatment types were tested: (1) control [C]; (2) BC $[\mathrm{BC}]$; (3) $\mathrm{BC}+$ T. viride $[\mathrm{BCT}]$; and (4) T. viride $[\mathrm{T}]$. The experimental field was established in Dobele region, Latvia. Eight plots with a two $100-\mathrm{cm}$-long rows in each were established with a buffer zone of $100 \mathrm{~cm}$ between the rows. Four treatment types were randomly applied on the plots in duplicate. For treatment, $250 \mathrm{~g} \mathrm{BC}$ was applied (alone or with T. viride) in the strips $(5 \times 100 \mathrm{~cm})$, mixing with soil in a 10-cm depth. Maize cv. 'Ambrozja' F1 seeds (16 seeds per one plot) were sown along the $\mathrm{BC}$ strip in two parallel rows, eight seeds from each side (distance between seeds $11 \mathrm{~cm}$ ), with a $5 \mathrm{~cm}$ distance from $\mathrm{BC}$.

T. viride (obtained from the Culture Collection of Microorganisms of the Institute of Microbiology and Biotechnology, University of Latvia) was cultivated (25 \pm $2{ }^{\circ} \mathrm{C}, 230 \mathrm{rpm}, 72 \mathrm{~h}$ ) in a liquid medium with the following composition $\left(\mathrm{g} \mathrm{L}^{-1}\right)$ : $\left(\mathrm{NH}_{4}\right)_{2} \mathrm{SO}_{4} 5.0 ; \mathrm{KH}_{2} \mathrm{PO}_{4} 15.0 ; \mathrm{MgSO}_{4}$ $0.6 ; \mathrm{CaCl}_{2} 0.6 ; \mathrm{FeSO}_{4} 7 \mathrm{H}_{2} \mathrm{O} 0.005 ; \mathrm{MnSO}_{4} \mathrm{H}_{2} \mathrm{O} 0.002$; $\mathrm{ZnSO}_{4} 7 \mathrm{H}_{2} \mathrm{O}$ 0.002; $\mathrm{CoCl}_{2} 0.002$; molasses 5.0. The number of colony forming units (CFU) in culture was determined by cultivation on Rose Bengal Agar with chloramphenicol (Biolife, Italy). CFUs were counted after plate incubation for $72 \mathrm{~h}$ at $25 \pm 2{ }^{\circ} \mathrm{C}$. One litre culture $\left(1.4 \times 10^{7} \mathrm{CFU} \mathrm{L}^{-1}\right)$ was mixed with $250 \mathrm{~g}$ autoclaved $\left(121^{\circ} \mathrm{C}, 15 \mathrm{~min}\right) \mathrm{BC}$ and incubated overnight at $24^{\circ} \mathrm{C}$. In the case of soil treatment by T. viride alone, $1 \mathrm{~L}$ per plot of T. viride culture was added to soil.

The experiment lasted for 128 days, in the period from June 9, 2014 until October 15, 2014. Seed germination and plant growth were monitored during the first 14 days and 55 days, respectively. Monthly average temperatures of air and soil surface are summarized in Fig. 1. The average rainfall in June, July, August, September and October was $4.0 \mathrm{~mm}$ (14 rainy days); $5.2 \mathrm{~mm}$ (9 rainy days); $5.9 \mathrm{~mm}$ (19 rainy days); $5.5 \mathrm{~mm}$ (8 rainy days) and $21.5 \mathrm{~mm}$ (6 rainy days), respectively (www.meteo.lv).

\section{Analytical testing}

Soil textural class was determined as sandy loam, according to the Guidelines for Soil Description (FAO 2006).

Dry weight of soil was determined after drying at $105{ }^{\circ} \mathrm{C}$ till constant weight. Soil $\mathrm{pH}$ was measured with a glass electrode in $1 \mathrm{M} \mathrm{BaCl}$ extract (1:2.5 mass to volume ratio). Exchangeable elements $\left(\mathrm{Ca}^{2+}, \mathrm{Mg}^{2+}\right.$, $\mathrm{K}+, \mathrm{Na}^{+}, \mathrm{Al}^{3+}, \mathrm{Fe}^{3+}, \mathrm{Mn}^{4+}$ ) were determined by an atomabsorption spectrophotometer (PerkinElmer AAnalyst 200), subsequently calculating element concentrations in 


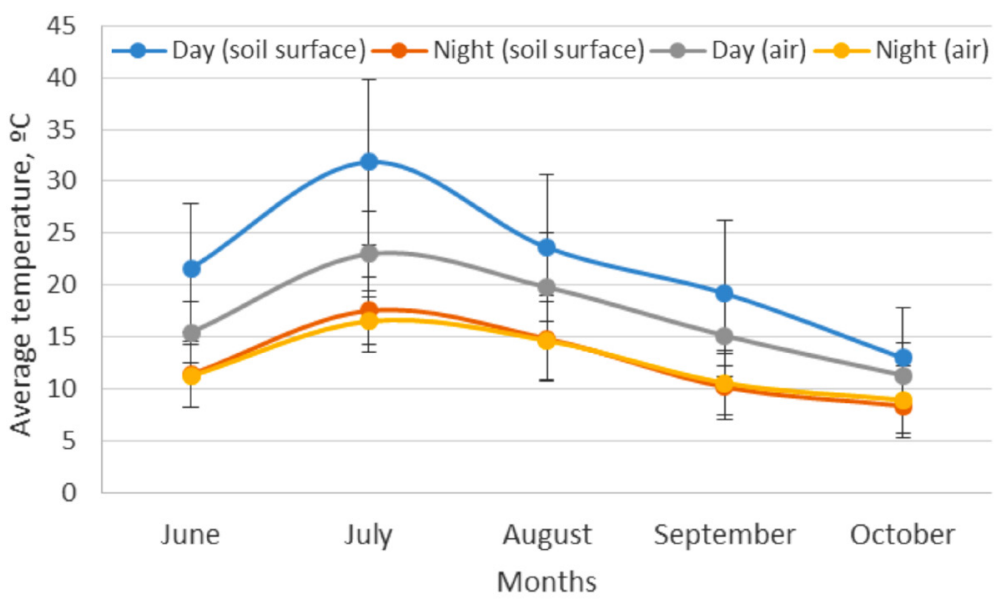

Fig. 1. Monthly average temperatures of air and soil surface in the period from June 92014 till October 152014 (www.meteo.lv, "Latvian Environment, Geology and Meteorology Centre).

$\mathrm{mg} \mathrm{kg}$. Total nitrogen and total carbon concentration (\%) were determined using a CHNS-O Elemental Analyzer EA3000 Series (EuroVector). Chemical analysis of elements was carried out in three replicates. The laboratory results were considered acceptable when the difference between the values obtained was less than $\pm 5 \%$.

Soil was characterized by the following parameters: $\mathrm{pH}_{\mathrm{BaCl}_{2}} 7.27 \pm 0.03 ; \mathrm{C}_{\text {tot }} 4.94 \pm 0.80 \% ; \mathrm{N}_{\text {tot }} 0.39 \pm 0.04$; exchangeable cations $\left(\mathrm{mg} \mathrm{kg}^{-1}\right) \mathrm{Na}^{+} 28.4 \pm 2.50 ; \mathrm{Mg}^{2+} 428.9$ $\pm 26.2 ; \mathrm{K}^{+} 312.1 \pm 12.3 ; \mathrm{Ca}^{2+} 6537.0 \pm 434.6 ; \mathrm{Al}^{3+} 0.9 \pm 0.1$; $\mathrm{Fe}^{3+} 0.08 \pm 0.00 ; \mathrm{Mn}^{4+} 0.24 \pm 0.04$.

The aboveground biomass of maize after 128 days cultivation was tested at the Analytical Laboratory, Latvia University of Agriculture. The samples were prepared according to standard methods (ISO 6496: 1999; LVS EN ISO 6498: 2012). The dry weight of the aboveground part of harvested plants was determined by sample drying at $60{ }^{\circ} \mathrm{C}$ followed by tissue crushing and subsequent drying at $105{ }^{\circ} \mathrm{C}$ till constant weight. The total carbon (CS-500) concentration was determined by the Analyzer ELTRA method, acid detergent fibre was measured according to LVS EN ISO 13906: 2008, and crude protein concentration was calculated using nitrogen analysis performed by block digestion and steam distillation (LVS EN ISO 5983-2: 2009). Two plants were sampled from each plot (overall four plants per one treatment type).

\section{Microbiological testing}

For microbiological testing, $1 \mathrm{~g}$ soil from the rhizosphere was taken after the 128 days vegetation experiment in triplicate. The soil-water suspensions were diluted serially and spread on agar media. Fungi were cultivated on Rose Bengal Agar with chloramphenicol (Biolife, Italy). CFUs were counted after plate incubation for $120 \mathrm{~h}$ at $25 \pm 2{ }^{\circ} \mathrm{C}$. Genera of cultivable filamentous fungi were determined after incubation for 10 days according to morphological characteristics and light microscopy results using identification keys (Watanabe 2002).

\section{Microscopy study}

BC particles were sampled from the maize rhizosphere after the experiment and analyzed for the presence of biofilm using a confocal laser scanning microscope (Leica DM RA-2, Germany) equipped with a TCS-SL confocal scanning head. Samples were fixed with $70 \%$ ethanol and stained with propidium iodide $(20 \mu \mathrm{M})$. Propidium iodide is a red-fluorescent nuclear and chromosome counterstain. Sample fixation with alcohol permeabilized the cells thus allow entry of the dye and access to the nucleic acids (Chu et al.,1999). Propidium iodide was excited at $488 \mathrm{~nm}$, and fluorescence was detected at $600-640 \mathrm{~nm}$. The reflected light of degraded organic matter was induced with a 488 $\mathrm{nm}$ band, and reflection was detected between 490 and 500 $\mathrm{nm}$.

\section{Identification of Trichoderma spp.}

Soil was sampled at the end of the vegetation experiment from the plant rhizosphere (four plants per each treatment type) and stored at $-20{ }^{\circ} \mathrm{C}$ until testing. Total DNA was extracted from each soil sample $(0.25 \pm 0.01$ g ) in duplicate using the PowerSoil ${ }^{\circledR}$ DNA Isolation Kit (MoBio Laboratories Inc., Carlsbad, CA, USA) following the manufacturer's instructions. Soil samples were homogenized using a horizontal Mixer Mill Type MM 301 (Retsch, Germany) at a maximum speed of $30 \mathrm{~Hz}$ for 10 minutes. The purity and concentrations of the extracted DNA were determined spectrophotometrically with a NanoDrop 2000 (ThermoScientific, USA) and by $0.8 \%$ agarose gel electrophoresis (Yeates et al. 1998). The DNA extracts were stored at $-20{ }^{\circ} \mathrm{C}$ until use. Quantitative PCR (qPCR) was performed using a 7300 Fast real-time Applied Biosystems PCR system and data analysis was carried out using the software supplied.

Molecular identification of Trichoderma spp. was performed with primer set uTf/uTr (Hagn et al. 2007). The qPCR reaction contained $1 \times$ Maxima SYBR Green/ROX qPCR Master Mix (Thermo Scientific), $0.2 \mu \mathrm{M}$ of each 

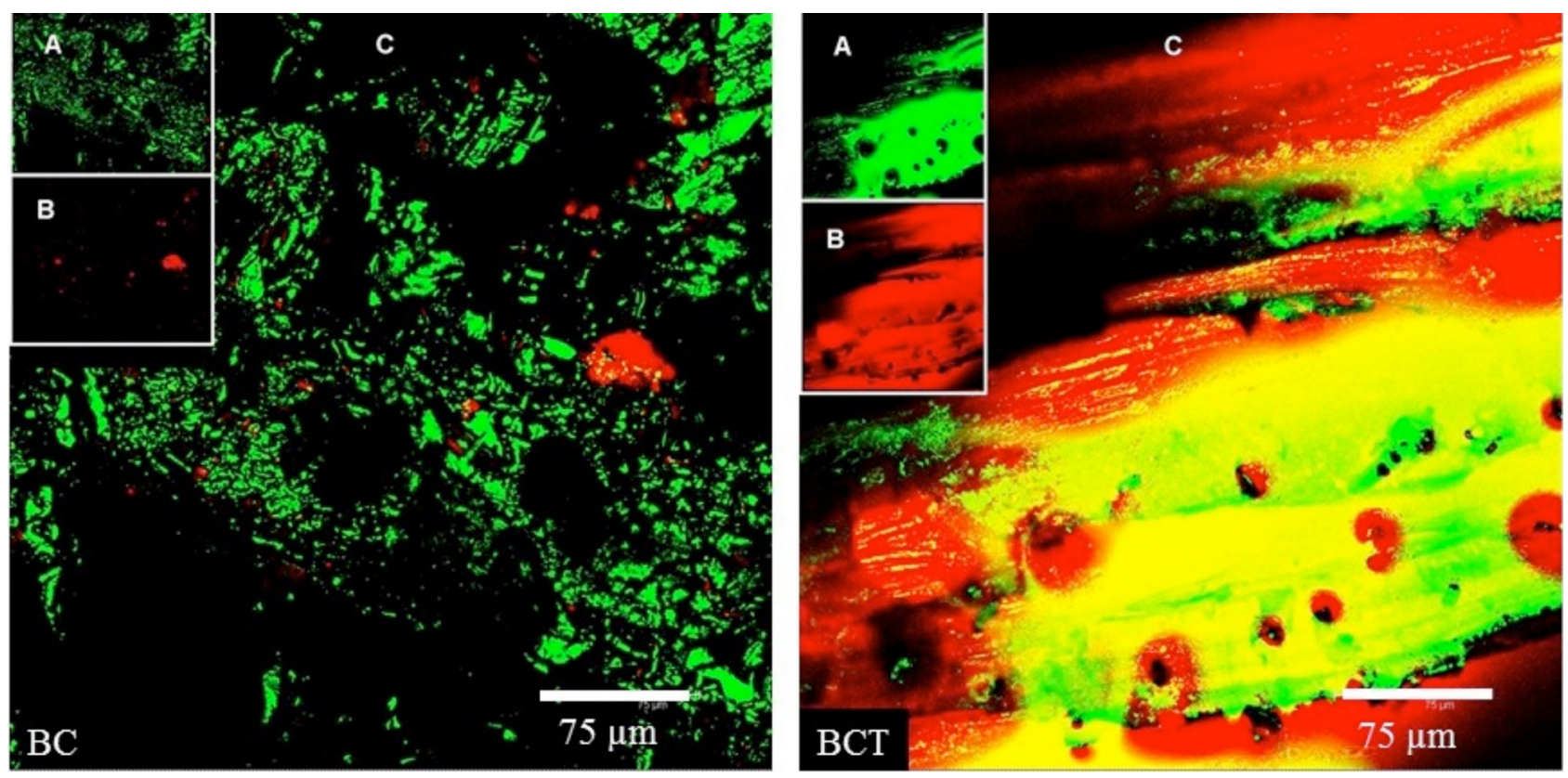

Fig. 2. Confocal laser scanning micrographs of the straw-derived biochar surface with biofilm. Biochar was sampled from soil after the vegetation experiment with maize. $\mathrm{BC}$, biochar; $\mathrm{BCT}, \mathrm{BC}+T$. viride. Green color corresponds to zones without nucleic acids (A), while red and yellow to zones with nucleic acids (B). C shows summary visualization of distribution of both zones. Black zones correspond to non-scanned surfaces situated either above or below the scanning zone.

primer, and $1 \mu \mathrm{L}$ of template DNA in a total volume of 25 $\mu \mathrm{L}$ reaction. The cycler conditions were as follows: initial $95^{\circ} \mathrm{C}$ for $10 \mathrm{~min}$ followed by 35 cycles of $95^{\circ} \mathrm{C}$ for $30 \mathrm{~s}, 55$ ${ }^{\circ} \mathrm{C}$ for $30 \mathrm{~s}$ and $72{ }^{\circ} \mathrm{C}$ for $60 \mathrm{~s}$ and detection. Trichoderma

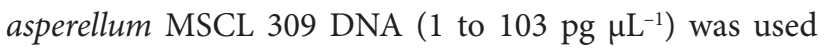
to make a standard curve for quantification. All reactions were done in triplicate. After quantification the samples were subjected to melting curve analysis and agarose gel electrophoresis.

\section{Statistical analysis}

The statistical data analysis was performed with single factor ANOVA using Microsoft Excel software at a significance level $p=0.05$.

\section{Results}

\section{Microscopy of biochar particles after the experiment}

Effect of $\mathrm{BC}$ with immobilized T. viride on maize growth was expected to differ from the effects of $\mathrm{BC}$ and fungi, which were applied separately. After the 128 days experiment, BC particles were sampled from the rhizosphere soil and tested under confocal laser microscopy in order to compare the pre-treatment of $\mathrm{BC}$ by Trichoderma [BCT] with the nontreated $\mathrm{BC}[\mathrm{BC}]$. As shown in Fig. 2, BC particles from [BCT] were covered by a dense continuous biofilm, while $\mathrm{BC}$ particles from $[\mathrm{BC}]$ contained only separate sites with viable organic matter. This indicated the suitability of the tested BC as a carrier for immobilization of T. viride.

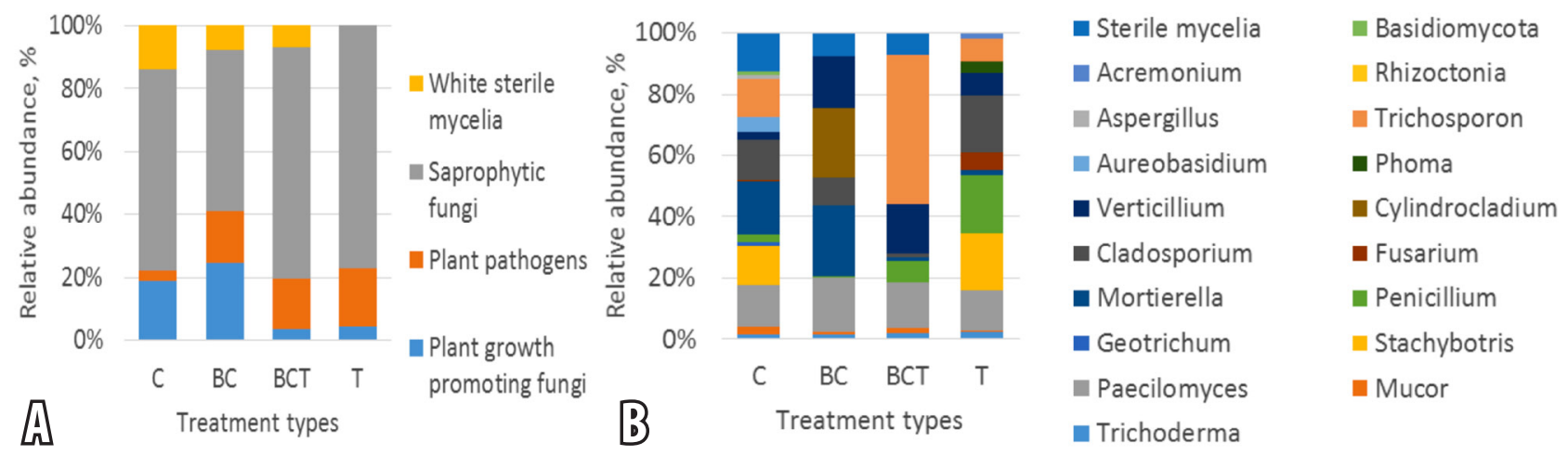

Fig. 3. Relative abundance of cultivable fungal genera in the maize rhizosphere after growth in a sandy loam soil for 128 days. A, three ecological groups of filamentous fungi and non sporulating white sterile mycelia; B, all fungal genera detected in soil. C, control; BC, biochar; $\mathrm{BCT}, \mathrm{BC}+$ T. viride; $\mathrm{T}, T$. viride. Data represent the average of 4 replicates. 


\section{Characteristics of cultivable fungi}

All identified cultivable sporulating fungi in the present investigation were divided into three ecological groups: plant pathogens, saprophytes and plant growth promoting fungi (Fig. 3). Genera belonging to the plant pathogens were: Fusarium, Verticillium, Phoma, Rhizoctonia, and Acremonium. Plant growth promoting genera were Trichoderma and Mortierella. Members of the genus Mortierella produce arachidonic acid, a suppressive agent against plant pathogenic fungi (Eroshin, Dedyukhina 2002; Fakas et al. 2009). Among saprophytic fungi the following genera were represented: Mucor, Stachybotrys, Geotrichum, Penicillium, Cladosporium, Aureobasidium, Trichosporon, Aspergillus, Cylindrocladium, and Paecilomyces.

Non-sporulating fungi were grouped in a separate group. $\mathrm{BC}$ treatment increased the relative abundance of plant growth promoting fungi, while other two treatments (BCT and $\mathrm{T}$ ) reduced the relative abundance of these fungi and increased the proportion of saprophytic fungi (Fig. $3 \mathrm{~A}$ ). BC treatment increased the relative abundance of Mortierella from 17.55 to $22.87 \%$, as previously observed in a study conducted in an apple orchard in Australia (Abujabhah et al. 2016).

Treatments $[\mathrm{BC}]$ and $[\mathrm{BCT}]$ increased the $\mathrm{CFU}$ count of Paecilomyces. Similar effect of BC on this fungal genus has been described also in another study on the effect of BC influence on soil microbial populations (Hu et al. 2014). All treatments increased the relative abundance of plant pathogenic fungi (Fig. 3).

\section{Abundance of Trichoderma in soil}

qPCR was used to quantify Trichoderma DNA in soil samples. A set of uTf/uTr primers used was developed by Hagn (2007) for the detection, identification and quantification of common Trichoderma species in soil samples .

The amount of the total soil DNA ranged from 11.9

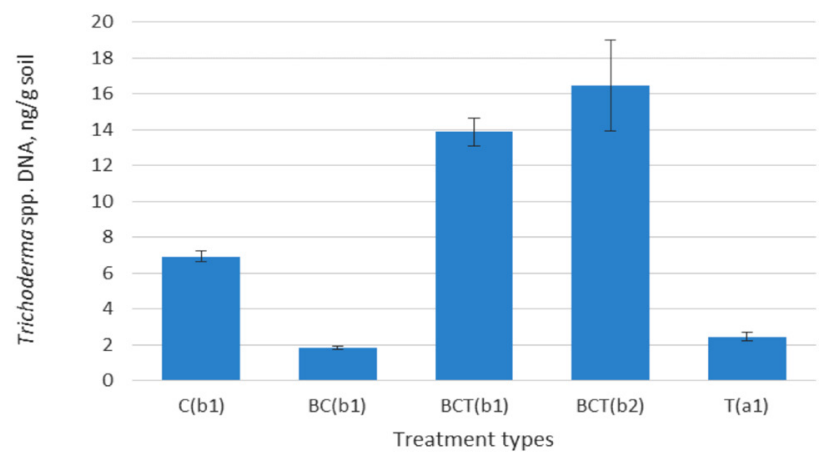

Fig. 4. Abundance of Trichoderma DNA in maize rhizosphere soil after 128 days. C, control; $\mathrm{BC}$, biochar; $\mathrm{BCT}, \mathrm{BC}+$ T. viride; $\mathrm{T}, \mathrm{T}$. viride. (a1); (b1); (b2), replications of treatment, soil was taken from different plants.

up to $19.3 \mu \mathrm{g} \mathrm{g}^{-1}$ of dry soil. Trichoderma spp. DNA was detected in 5 samples among 16, which represented four treatment types performed in four replicates (Fig. 4). In particular, for treatments $[\mathrm{C}] ;[\mathrm{BC}]$ and $[\mathrm{T}]$, Trichoderma DNA was detected in one sample of four replications, while for $[\mathrm{BCT}]$ in two samples. Moreover, the observed amount of Trihoderma DNA was highest in the [BCT] treatment (Fig. 4).

\section{Seed germination and plant growth}

The effect of $\mathrm{BC}$ and $T$. viride on maize was evaluated by seed germination and plant height. The highest seed germination among the tested treatments after 14 days was found in the $[\mathrm{BCT}]$ treatment $(87.5 \pm 0.0 \%)$, which was significantly $(p<0.05)$ different from that in the $[\mathrm{T}]$ treatment $(71.9 \pm 4.4 \%)$. Seed germination in treatment $[C]$ and $[\mathrm{BC}]$ was $75.0 \pm 8.8 \%$ and $78.1 \pm 4.4 \%$, respectively.

Effect of soil treatments on the maize growth after 18 days and 55 days was determined. As shown in Fig. 5, average height of plants grown in the presence of [BCT] exceeded other treatment types after 18 days and 55 days.
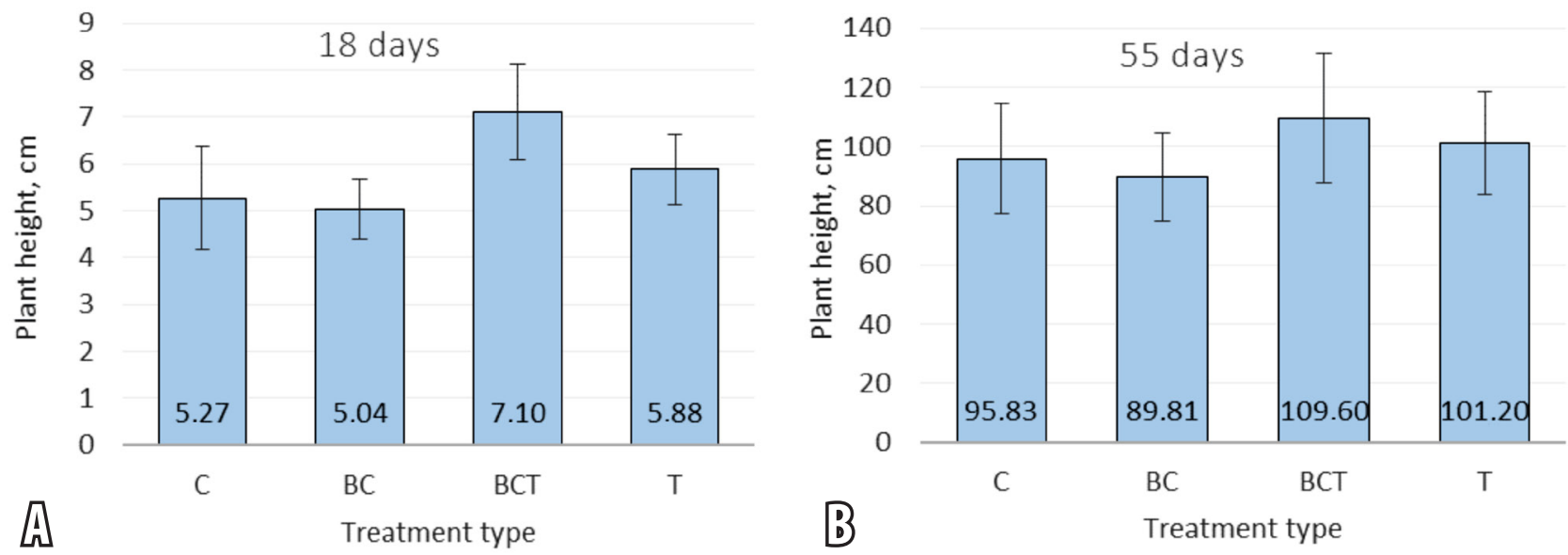

Fig. 5. Height of maize Zea mays growth under various treatment types after 18 days and 55 days from the beginning of the mini-field vegetation experiment. $\mathrm{C}$, control; $\mathrm{BC}$, biochar; $\mathrm{BCT}, \mathrm{BC}+\mathrm{T}$. viride; $\mathrm{T}, \mathrm{T}$. viride. The values represent averages from two plots for each treatment type. 
Table 1. Yield components and nutritional parameters of Zea mays aboveground biomass after 128 days. C, control; BC, biochar; BCT, $\mathrm{BC}+$ T. viride; $\mathrm{T}$, T. viride. Data represent the average of 4 plants. ${ }^{*}$, average levels in ten maize hybrids cultivated in the Zemgale region, Latvia and harvested in October $3^{\text {rd }}, 2009 .{ }^{* *}$, not determined

$\begin{array}{lccccc}\text { Parameter } & \text { C } & \text { BC } & \text { BCT } & \text { T } & \text { REF* } \\ \text { Dry weight (\%) } & 21.4 \pm 1.5 & 19.9 \pm 1.8 & 19.7 \pm 1.6 & 21.3 \pm 2.3 & 24.2 \\ \text { Carbon (\% DW) } & 44.9 \pm 1.9 & 46.7 \pm 0.3 & 45.3 \pm 1.6 & 45.0 \pm 1.5 & \text { n.d. }{ }^{* *} \\ \text { Crude protein (\% DW) } & 7.8 \pm 0.4 & 7.9 \pm 0.9 & 8.9 \pm 0.8 & 8.5 \pm 0.7 & 6.9 \\ \text { Acid detergent fiber (\% DW) } & 28.2 \pm 2.8 & 28.3 \pm 3.0 & 27.0 \pm 2.1 & 28.0 \pm 1.5 & 23.3\end{array}$

The difference between $[\mathrm{C}]$ and $[\mathrm{BC}]$ was not statistically significant, while treatment pairs $[\mathrm{BC}]$ vs $[\mathrm{BCT}] ;[\mathrm{C}]$ vs $[\mathrm{BCT}] ;[\mathrm{BC}]$ vs $[\mathrm{T}]$ showed significant $(p<0.05)$ differences in plant height for both measurement periods (Fig. 5).

\section{Biochemical characteristics of plant biomass after the vegetation experiment}

The aboveground biomass of maize was characterized in treatment effect on yield and forage quality potential of the crop. Table 1 summarizes the yield components and nutritional parameters of maize aboveground biomass after 128 days. No significant differences in the tested parameters among treatment types were found.

\section{Discussion}

In this study effects of the wheat straw derived $\mathrm{BC}$ and $\mathrm{T}$. viride alone and in combination on fungal diversity and maize growth in a sandy loam soil were determined. Soil was characterized by a high heterogenity in composition, which influenced the reproducibility of data obtained by culturedependent methods and molecular tools. It should be noted that because of the adsorption of DNA to $\mathrm{BC}$, microbial DNA extraction and purification from BC-amended soil can be difficult. Leite et al. (2014) compared different DNA extraction kits and showed that the PowerSoil kit was the most efficient for extracting microbial genomic DNA from soil treated with different types of biochar (Leite et al.2014). Some studies have shown that the incorporation of $\mathrm{BC}$ into soil may influence soil microbial communities in different ways (Lehmann et al. 2011). Distinction must be made between BCs derived from manure- and crop residuebased feedstocks versus BCs derived from ligno-cellulosic feedstock, as well as BCs produced at a lower production temperature $\left(<400{ }^{\circ} \mathrm{C}\right)$ versus $\mathrm{BCs}$ generated at a higher production temperature $\left(\geq 600^{\circ} \mathrm{C}\right)$ (Gul, Whalen 2016).

Addition of $\mathrm{BC}$ and T. viride to soil caused changes in the fungal community, i.e., relative abundance of three ecological groups: plant pathogens, saprophytes and plant growth promoting fungi. Several fungal ecological groups have been described, such as litter decomposing fungi, wood-attacking fungi, chitinolytic fungi, keratinophilic fungi, fungicolous fungi, coprophilous fungi, pyrophilous fungi, ammonia fungi (Suzuki 2009), plant pathogens, plant endophytes and saprophytes (Rodriguez, Redman 1997). Such divisions can be imprecise, as, for example, some pathogenic fungi can be also saprophytic, depending on environmental conditions and available food sources. For example, Fusarium species are well known plant pathogens in agriculture but they can act as decomposers and carbon sequestrators as well (LeBlanc et al. 2015).

Addition of BC with immobilized T. viride to soil significantly increased seed germination and growth of maize. In this respect, it could be hypothesized that the tested BC is suitable for Trichoderma immobilization and further survival in soil. This was shown by culture-dependent methods, qPCR and microscopy. Trichoderma itself could play a positive role for maize growth. Trichoderma may also promote leaching of nutrients from $\mathrm{BC}$, which should be tested in future experiments.

The treatment with $\mathrm{BC}$ and T. viride alone did not significantly influence seed germination and plant height, as compared to the control. It is important to emphasize the role of fertilizers in the case of $\mathrm{BC}$ addition to soil. Zhu et al. (2017) described the effect of maize-straw-derived $\mathrm{BC}$ at an application rate up to $30 \mathrm{tha}^{-1}$ on soil properties and maize growth. No significant effect of $\mathrm{BC}$ on nitrogen uptake by seedlings, plant height, biomass dry weight was found. Conversely, cultivation of maize in a glasshouse for 45 days in a sandy podzol soil with addition of BC (30 t $\mathrm{ha}^{-1}$ ) resulted in increased dry matter and plant height. The authors found that $\mathrm{BC}$ alone is not able to supply enough nutrients for maize growth, and that additional fertilizers are required (Syuhada et al. 2016). In particular, Fe fertilization with BC might be beneficial for maize growth and $\mathrm{Fe}$ bioavailability, resulting in increasing starch, protein and fat concentrations in the plants (Ramzani et al. 2016).

Our vegetation experiment with maize did not include additional fertilizer treatment. According to recommendations (Karklins, Ruza 2013), additions of different amounts of $\mathrm{N}, \mathrm{P}_{2} \mathrm{O}_{5}$ and $\mathrm{K}_{2} \mathrm{O}$ result in a range of maize yield from 30 up to $80 \mathrm{tha}^{-1}$ in Latvia. In particular, the application rate of $\mathrm{N}$ in the case of maize cultivation should be from 100 to $180 \mathrm{~kg} \mathrm{ha}^{-1}$ and it is recommended to divide this amount into three applications, i.e., at the beginning of cultivation, in the 5 to 6 leaf stage, and in the 8 to 10 leaf stage (Karklins, Ruza 2013). The concentration of $\mathrm{N}$ in the tested soil was $0.39 \pm 0.04 \%$, which was not sufficient for obtaining the maximum maize yield. Furthemore, maize yield depends on climatic conditions, particularly active temperature sum and precipitation (Gaile, Arhipova 2015). 


\section{Acknowledgements}

The study was financialy supported by the project "Sustainable use of nature resources in the context of climate changes" No. ZD2016 AZ03; the National Research Programme of Latvia 2014.10-4/ VPP-6/6 "Sustainable Use of Forests and Mineral Deposits - New Products and Technologies (ResProd). Assistance of Krisjanis Stelmahers in maintenance of the vegetation experiment is greatly appreciated.

\section{References}

Abujabhah I.S., Bound S.A., Doyle R., Bowman J.P. 2016. Effects of biochar and compost amendments on soil physico-chemical properties and the total community within a temperate agricultural soil. Appl. Soil Ecol. 98: 243-253.

Arif M., Ilyas M., Riaz M., Ali K., Shah K., Ul Haq I., Fahad S. 2017. Biochar improves phosphorus use efficiency of organicinorganic fertilizers, maize-wheat productivity and soil quality in a low fertility alkaline soil. Field Crops Res. 214: 25-37.

Bartusevics J., Gaile Z. 2009. Influence of maize hybrid and harvest time on yield and substrate composition for biogas production. In: Research for Rural Development 2009. Latvia University of Agriculture, Jelgava, 20-22 May 2009, pp. 44-49.

Chan K.Y. 2007. Agronomic value of green waste biochar as a soil amendment. Soil Res. 45: 629-634.

Chu Y.W., Wang R., Schmid I., Sakamoto K.M. 1999. Analysis with flow cytometry of green fluorescent protein expression in leukemic cells. Cytometry 36:333-339.

El-Katatny M.H., Idres M.M. 2014. Effects of single and combined inoculations with Azospirillum brasilense and Trichoderma harzianum on seedling growth or yield parameters of wheat (Triticum vulgaris L., Giza 168) and corn (Zea mays L., Hybrid 310). J. Plant Nut. 37: 1913-1936.

Eroshin V.K., Dedyukhina E.G. 2002. Effect of lipids from Mortierella hygrophila on plant resistance to phytopathogens. World J. Microbiol. Biotechnol. 18: 165-167.

Fakas S., Makri A., Mavromati M., Tselepi M., Aggelis G. 2009. Fatty acid composition in lipid fractions lengthwise the mycelium of Mortierella isabellina and lipid production by solid state fermentation. Bioresour. Technol. 100: 6118-6120.

Faloye O.T., Alatise M.O., Ajayi A.E., Ewulo B.S. 2017. Synergistic effects of biochar and inorganic fertiliser on maize (Zea mays) yield in an alfisol under drip irrigation. Soil Till. Res. 174: 214-220.

Gaile Z. 2012. Maize (Zea mays L.) response to sowing timing under agro-climatic conditions of Latvia. ŽemdirbystéAgriculture 99: 31-40.

Gaile Z., Arhipova I. 2015. Influence of meteorological factors on maize performance in Latvia. Proc. Latvian Acad. Sci. B 69: 68-76.

Głodowska, M., Husk B., Schwinghamer T., Smith D. 2016. Biochar is a growth-promoting alternative to peat moss for the inoculation of corn with a pseudomonad. Agron. Sust. Dev. 36: $1-10$.

Gonzaga M.I.S., Mackowiak C.L., Comerford N.B., Moline E.F.D.V., Shirley J.P., Guimaraes D.V. 2017. Pyrolysis methods impact biosolids-derived biochar composition, maize growth and nutrition. Soil Till. Res. 165: 59-65.

Gul S., Whalen J.K. 2016. Biochemical cycling of nitrogen and phosphorus in biochar-amended soils. Soil Biol. Biochem. 103: $1-15$.
Hagn A., Wallisch S., Radl V., Munch J.C., Schloter M. 2007. A new cultivation independent approach to detect and monitor common Trichoderma species in soils. J. Microbiol. Meth. 69: 86-92.

Hale L., Luth M., Crowley D., 2014. Biochar characteristics relate to its utility as an alternative soil inoculum carrier to peat and vermiculite. Soil Biol. Biochem. 81: 228-235.

Harman G.E., Petzoldt R., Comis A., Chen J. 2004. Interactions between Trichoderma harzianum strain T22 and maize inbred line Mo17 and effects of these interactions on diseases caused by Pythiuin ultimum and Colletotrichum graminicola. Phytopathology 94: 147-153.

Hermosa R., Viterbo A., Chet I., Monte E. 2012. Plant-beneficial effects of Trichoderma and of its genes. Microbiology 158: $17-25$.

Hu L., Cao L., Zhang R. 2014. Bacterial and fungal taxon changes in soil microbial community composition induced by shortterm biochar amendment in red oxidized loam soil. World J. Microbiol. Biotechnol. 30: 1085-1092.

Karklins A., Ruza A. (eds) 2013. Fertiliser Recommendations for Agricultural Crops. LLU, Jelgava. http://www.vmd. gov.lv/public/ck/files/ZM/lauksaimnieciba/Lauku\%20 kulturaugu\%20mesl\%20normativi.pdf

Keady T.W.J. 2005. Ensiled maize and whole crop wheat forages for beef and dairy cattle: effect on animal performance. Silage production and utilisation. In: Park R.S., Stronge M.D. (eds) Proceedings of the XIV International Silage, Conference, a satellite workshop of the XX international Grassland Congress, Wageningen Academic Publishers, the Netherlands, pp. 65-82.

Kerré, B., Willaert, B., Cornelis, Y., Smolders, E. 2017. Long-term presence of charcoal increases maize yield in Belgium due to increased soil water availability. Eur. J. Agr. 91: 10-15.

Lamdan N.L., Shalaby S., Ziv T., Kenerley C.M., Horwitz B.A. 2015. Secretome of Trichoderma interacting with maize roots: role in induced systemic resistance. Mol. Cell. Proteom. 14: 1054-1063.

LeBlanc N., Kinkel L.L., Kistler H.C. 2015. Soil fungal communities respond to grassland plant community richness and soil edaphics. Microb. Ecol. 70: 188-195.

Lehmann J., Rillig M.C., Thies J., Masiello C.A., Hockaday W.C., Crowley D. 2011. Biochar effects on soil biota - a review. Soil Biol. Biochem. 43: 1812-1836.

Leite D.C., Balieiro F.C., Pires C.A., Madari B.E., Rosado A.S., Coutinho H.L., Peixoto R.S. 2014 Comparison of DNA extraction protocols for microbial communities from soil treated with biochar. Braz. J. Microbiol. 45: 175-83.

Ĺopez-Coria M., Herńandez-Mendoza J.L., Śanchez-Nieto, S. 2016. Trichoderma asperellum induces maize seedling growth by activating the plasma membrane $\mathrm{H}^{+}$-ATPase. Mol. PlantMicrobe Interact. 29: 797-806.

LVS EN ISO 13906: 2008. Determination of acid detergent fibre (ADF) contents.

LVS EN ISO 5983-2: 2009. Determination of nitrogen content and calculation of crude protein content-part 2: Block digestion and steam distillation method.

LVS EN ISO 6496: 1999. Determination of moisture and other volatile matter content.

LVS EN ISO 6498: 2012. Animal feeding stuff - Guidelines for sample preparation.

Muter O., Berzins A., Strikauska S., Pugajeva I., Bartkevics V., Truu J., Truu M., Steiner C. 2014. The effects of woodchip- 
and straw-derived biochars on the persistence of the herbicide 4-chloro-2-methylphenoxyacetic acid (MCPA) in soils. Ecotoxicol. Environ. Saf. 109: 93-100.

Naeem M.A., Khalid M., Aon M., Abbas G., Tahir M., Amjad M., Murtaza B., Yang A., Akhtar S.S. 2017. Effect of wheat and rice straw biochar produced at different temperatures on maize growth and nutrient dynamics of a calcareous soil. Arch. Agr. Soil Sci. 63: 2048-2061.

Ramzani P.M.A., Khalid M., Anjum S., Khan W., Iqbal M., Kausar S. 2016. Improving iron bioavailability and nutritional value of maize (Zea mays L.) in sulfur-treated calcareous soil. Arch. Agr. Soil Sci. 63: 1255-1266.

Rangel D.E.N., Alder-Rangel A., Dadachova E., Finlay R.D., Dijksterhuis J., Braga G.U.L., Corrochano L.M., Hallsworth J.E. 2015. The International Symposium on Fungal Stress: ISFUS. Curr. Gen. 3: 479-487.

Rehman M.Z.-U., Rizwan M., Ali S., Fatima N., Yousaf B., Naeem A., Sabir M., Ahmad H.R., Ok Y.S. 2016. Contrasting effects of biochar, compost and farm manure on alleviation of nickel toxicity in maize (Zea mays L.) in relation to plant growth, photosynthesis and metal uptake. Ecotoxicol. Environ. Saf. 133: 218-225.

Rodriguez R.J., Redman R.S. 1997. Fungal life-styles and ecosystem dynamics: biological aspects of plant pathogens, plant endophytes and saprophytes. Adv. Bot. Res. 24: 169-193.

Romão-Dumaresq A.S., Dourado M.N., De Fávaro L.C.L., Mendes R., Ferreira A., Araújo W.L. 2016. Diversity of cultivated fungi associated with conventional and transgenic sugarcane and the interaction between endophytic trichoderma virens and the host plant. PLoS ONE 11: e0158974.

Saldajeno M.G.B., Naznin H.A., Elsharkawy M.M., Shimizu M., Hyakumachi M. 2014. Enhanced resistance of plants to disease using Trichoderma spp. In: Gupta V.G., Schmoll M., Herrera-Estrella A., Upadhyay R.S., Druzhinina I., Tuohy M. (eds) Biotechnology and Biology of Trichoderma. Elsevier, pp. 477-493.

Sarfraz R., Shakoor A., Abdullah M., Arooj A., Hussain A., Xing S. 2017. Impact of integrated application of biochar and nitrogen fertilizers on maize growth and nitrogen recovery in alkaline calcareous soil. Soil Sci. Plant Nutr. 63: 488-498.

Syuhada A.B., Shamshuddin C.I., Fauziah C.I., Rosenani A.B., Arifin A. 2016. Biochar as soil amendment: impact on chemical properties and corn nutrient uptake in a Podzol. Can. J. Soil Sci. 96: 400-412.

Tan Z., Lin C.S.K., Ji X., Rainey T.J. 2017. Returning biochar to fields: a review. Appl. Soil Ecol. 116: 1-11.

Wang M., Ma J., Fan L., Fu K., Yu C., Gao J., Li Y, Chen J. 2015. Biological control of southern corn leaf blight by Trichoderma atroviride SG3403. Biocontrol Sci. Technol. 25: 1133-1146.

Watanabe T. 2002. Pictorial Atlas of Soil and Seed Fungi: Morphologies of Cultured Fungi and Key to Species. $2^{\text {nd }}$ Ed. CRC Press, Boca Raton.

Yeates C., Gillings M.R., Davison A.D., Altavilla N., Veal D.A. 1998. Methods for microbial DNA extraction from soil for PCR amplification. Biol. Proceed. Online 1: 40-47.

Zeilinger S., Gruber S. 2014. Insights into signaling pathways of antagonistic Trichoderma species. In: Gupta V.G., Schmoll M., Herrera-Estrella A., Upadhyay R.S., Druzhinina I., Tuohy M. (eds) Biotechnology and Biology of Trichoderma. Elsevier, pp. 465-476.

Zhu L.-X., Xiao Q., Shen Y.-F. Li S.-Q. 2017. Microbial functional diversity responses to 2 years since biochar application in siltloam soils on the Loess Plateau. Ecotoxicol. Environ. Saf. 144: 578-584. 